\title{
Importance of the Innovative Business Models for the Future Success of the Company
}

\author{
Leyla Djuraeva ${ }^{1 *}$ \\ ${ }^{1}$ Tashkent Branch of Moscow State University, named after M.V. Lomonosov, Tashkent 100000, Uzbekistan
}

\begin{abstract}
During the last decade, the market environment for the businesses has been influenced by digital developments and as a result, the focus on business model innovations has rapidly grown. Businesses started moving away from the classic method of creating competitive advantage like a new product development. Thus, this influenced business activities as well as companies' business models into innovations of new products and services, a new ways of company relationships with customers and employees. Customers started expecting to receive services at a level comparable to digital solutions. Simultaneously, it put pressure on organizations to reflect on their current strategy and discover new business opportunities at the early stages. Digitalization is a one of the significant reasons for innovation on the business model of companies. Currently, business model as a tool is becoming a very popular topic due to its benefits received by companies and this topic studied by various researchers. This paper is based on theoretical perspective and the study was done by analysing previous researches, articles and papers in the present context. The study emphasizes that business model innovation can be a basis of sustainable competition for companies and innovators may increase their returns 4 times than product and service developers.
\end{abstract}

\section{Introduction}

Current business world is influenced by tremendous factors, and it is very challenging to survive for companies in this rapidly changing environment. In 21 century, well-known Companies like Uber, Airbnb and Xiaomi became one of the leading companies in their respective industries because of their unique business models [1]. Nowadays, companies and organizations are keen for profitable growth, for being competitive and stay sustainable in the market. In major industries, innovations considered to be in the form of new products and services [2]. Of course, service innovations are vital for the business growth and considered as an important factor for competitive pressure, but innovations in a business model became on priority level. As of today, the effective business model for the companies are key to future success [3]. There is no future growth for a company, which cannot transform itself and develop a practical and effective business model, as it will lose its strength and die.

For every company, business model is considered as a logical key to perform, a system approach to create a value for its stakeholders. Thus, business models always existed and always will. Companies always had opportunities to create new business models that may change the standard rules of an industry, such as Kodak and Zara. However, taking into considerations of rapid speed of technological progress in current days, businesses also dictated by technological changes to do things in radically different ways [2]. Therefore, there is a tremendous increase in opportunities for innovation in business models, and same as the threats posed by innovations in competitors' business models. A business model innovation is a new approach to create value for customers taking into consideration digital changes, and how this value is carried or how the business gains profits from the service/product offered to the customer.

Business models for a company also known as a plan or a strategy that describes value chain delivery to final customers [2]. In the practice, startups are keen to use business models as modeling tools to plan, des ign and build their new projects. However, established and well-known companies also use them to develop and succeed to support their innovation process.

Professor Haim Mendelson from Standford University discusses the progress of business models and the impact of the developments in information technology. In his research, he illustrates, that by implementing it and digitalization the companies advances their business processes and becomes progressed in the market [3]. He also states that changes that are incorporated into the new business model of the company, will gain more benefits. As per professor Ricarts research paper, technology is main force to drive the change today, particularly information and communication technologies [3].

In the same research, author underlines, as it was mentioned above, business model concept emphases on the way the business creates value and adds revenues and profits. Based on this theory. He defines model into three core elements: a value-creation model, a profit model, and the logic of the business. 
Well known researchers, Raphael Amit and Christoph Zott stated that the focus area of business model has one of the significant positions for managers and academic researchers mainly for 3 reasons. Firstly, in the current world, Innovative business model indicates as an underutilized source of future value. Secondly, it gives competitor advantage, as other market players will face difficulties to imitate a complete innovative activity system than a single new product or process. Thirdly, management of the company should never challenge the effort of their competitor's in business model area as innovations considered a powerful competitive tool [4]. Actually, the business model in the digital economy grows into the success formula and it is gaining the power to establish a competitive advantage [5]. There are a huge number of examples in current business world to support these arguments, including such as examples of Dell Computers, IKEA and Southwest Airlines. Though there is an increasing number of research studies on this topic for last decade, researches usually consider Business models and tools from the technical aspects -elements of the business model, how can be innovated within the business model and how this innovation process can be implemented [5]. There are very few research studies about the consequences of innovations in business model in the business and its problems. Previous researchs on business model innovation has concentrated on how innovative changes in the company affect the business model [6]. Thus, there is a still distinct gap in research on interrelation of success and competitive advantage with innovative business model.

We have reviewed list of articles and empirical studies on this topic, analysed the opinions and statements of scholars which are presented in this paper below. This paper is constructed on the following way. Firstly, the theoretical background on this research topic will be stated, where the concept of the innovative business model and its importance, its influence on the business of the companies will be analyzed. After that, different views and results of the previous researchers will be compared and stated. Finally, the paper will provide summary on the results.

\section{Research Purpose and Research Question}

The issue of innovations in business model and its effectiveness were already identified almost decades ago in one of the oldest research papers of Zoe, Osterwelder [18 and 19]. Nowadays, reaction of management on changes happening from environment, technology or other factors and reflection of these alterations on the company's business model is vital [4]. Recently, a few scholars started to research the interrelation of changes in the market and business model innovation [13]. However, this topic on business model innovations still lacks of practical and clear analysis on how implementation of these changes in business model of the company occurs. Based on this research gap, proper research purpose is identified. The purpose of this thesis is to identify the effectiveness of innovative business models in the context of the company, benefits gaining from its implementation. In doing so, the researcher seeks to explore how successful can be companies which totally innovates their business model rather than invests on other projects. Consequently, the research question in this work will be: Will the Companies succeed by implementing innovative business model ?

\section{Methodology}

The purpose of this research is to examine how the innovations in the business models may influence the successfulness of the company in the market. To answer the research question, the researcher will examine the existing literature review and also qualitative research method is chosen to generate more accurate data. The Researcher will observe and create semi-structured interviewes with 2 largest companies in the developing country, which are successfully innovated existing business models.

\section{Theoretical Background}

In this section, we will review existing scholars and articles on this topic, empirical studies and summarize key ideas, statements which illustrate the importance of this topic nowadays.

\subsection{Theoretical Background}

The main purpose of the Theoretical Background section is to provide a reader with the literature overview in the respective areas of the business. Aligned with the research question and research goal, conceptual background offers a literature review in the field of innovation management and types of innovations, business model, , competitive advantage and at the end, the connection between competitive advantage and business model innovations. Also, different studies will be analyzed and compared on the effectiveness on the innovative business model of the current technologically progressed world.

Nowadays, change can be seen everywhere, the world is changing very fast, thus society has been under greater impact of them and trying to adopt to these changes. One of the global issues is significant changes in the technological sphere and transformation of major processes, activities and the business through digitalization. Digitalization is a new concept of last few decades and it plays major role in success of organization. Digitalization has spread been widely extended to every organization and has become an integral component of the modern world, as a result, it is hard to imagine an organization without implementation of innovative tools in current world [4, 7]

In the digital business world, information has been vital resource and newly established companies, 
startups in different industries, take advantage of this culture and economic change to perfection [18]. As a result, these new small companies are devastating the business of big organizations and increasing market from traditional brands.

In order to face successfully to market changes such as the case of the progressive rise of the digital business environment, existing organizations must be able to quickly shift and adopt changes. They have to maintain a variety of innovation efforts to operate more efficiently and deliver greater value to their customers [6].

As earlier described, digital technology can considerably contribute to a company's business model, which supports the companies' purpose; profit and growth [6].

One of the earlier researchers, Raphael Amit and Christoph Zott, provided in depth analysis on the topic of business model innovation and its importance for managers and academic researchers. Strategic discussions on the Business model and influence of digitalization and IT were enormous, and there is no still one defined compromise on this topic.

Design parameters of Zott \& Amit (2010) business model ontology

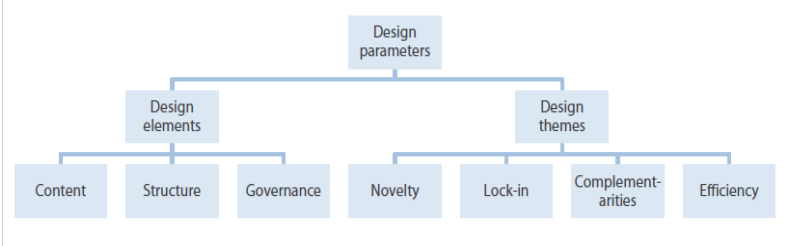

Fig. 1. Zott and Amit business model design parameters

These researchers conceptualize business model as a general system of activities correlated with each other and consequently, during the process of innovating business process 2 parameters: design elements and design themes for activity system should be done (for details refer to Fig 1.) [23]. The researchers explains that by interrelating each of these components shown in Fig 1, business model can be properly constructed in order to achieve greater efficiency [23]. They also presented 10 year-long research programs on business models and draw a parallel between digitalization and business model innovation [4]. Thus, business model innovation has been acknowledged as a new method of gaining competitive advantage for mature companies [3].

There are variety of business models that adopts innovations to stay digitalize. The study of digitalization and the effect of information technology on companies and their success have been critical to various researchers [13]. The Power of business models and their success has been analysed firstly through it related and mobile communication related industry [2]. In his research, the two cases Apple and HTC were investigated and results identified illustrates that implementation of new business model with innovations and digitalization assisted to derive revenue and boost income of the company. Innovations and business models with consideration of digitalization can be applied not only in the sphere of IT, but also can yield more benefits in other industries. As per research paper of Lee and Vonortas [9], a business model comprises of multiple components or elements. Though referred to previous studies such as Rayport and Jaworski [8] where business model is based on 4 choices, such as

- a "value proposition" or a value chain for niche customers;

- coverage of different type of products services or information (or combination of all of them) for covering market needs;

- An exclusive and secure resource system for benefit creation, such as, the "associated resource system";

- Appropriate model for financial system of the company, which covers, income and return models, shareholder value models, and future growth models.

In the same study, another researcher [3] proposed 4 components for digitalized business model framework:

product innovation or value proposition, customer relationship, infrastructure management, and financial aspects that can be found throughout the three former components, such as cost and revenue structures. To summarize their investigations, business model in new digital world may vary with different components, thus there is no clear definition of ideal business models for generation of income [4]. Another well known researchers Johnson and Christensen also supports idea of 4 components which interrelates and in sum delivers value to the customer [23]. The model is developed almost decade ago, but it is still considered as a basis for planning the business model innovations topic.

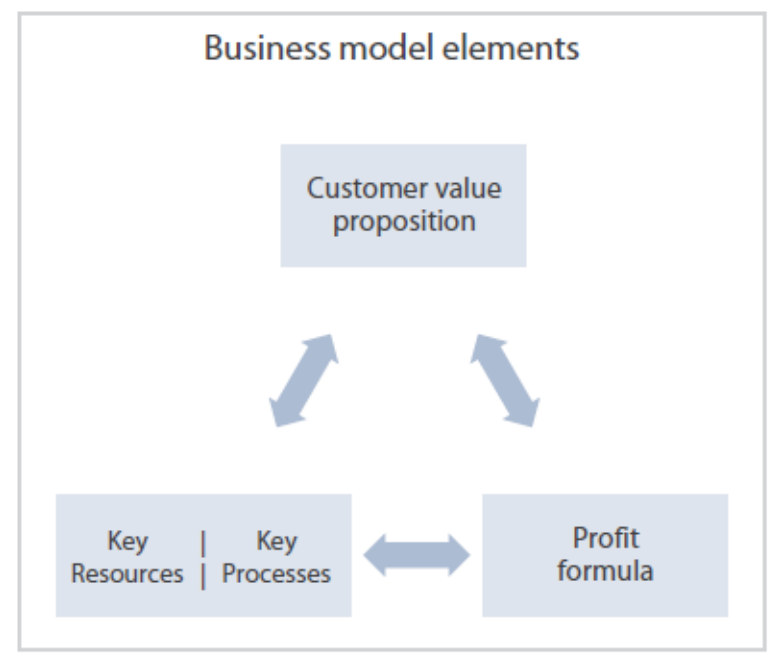

Fig. 2. Business model components from the Johnson\&Christensen

Referring to the study of Johnson, Christensen and Kagermann [12], which has illustrated the four elements that in total create, deliver and capture value. These are considered as "customer value proposition" (CVP), formula for profit model, basic resources and vital processesThis model also illustrates that the companies oriented on value creation recognize that 
each business component has significant role for success in the model [23]. Change of any of them will lead to the loss or profit of the company as the value proposition may be affected.

The differences of Business model innovations related in digitalization has been studied and analyzed in depth already few decades ago. In the summary report of Lee and Vonortas, several examples were presented were value creation of companies differs in digital and physical economy. According to the study of Meredith and Schaffer [7], in the industrial economy the main purpose of the management is to develop the physical transformation process by implementing management techniques, while in the digital economy, digital data and it is vital and main input into a business transformation process.

The digitalization allowed growing to a number of new business models and these models can be used in birth traditional business and in more innovative businesses. Innovation in the digital world concept as a quick development of new business models, it can also rapidly cause existing businesses to become outdated $[10,11]$.

According to the general data gathered through different studies and researches, business models of Amazon, Walmart and Target accounted for $76 \%$ of market capitalization in retail industries by 2007 , earning more than $\$ 300$ billion of value [14]. Furthermore, Comparable results have been proven in the airline industry, rental industry, digital communications and others, which illustrates the importance of proper developed Innovative Business model in business environment in current world.

Another interesting statement was found in the research of Eksell and Harenstam [6], were evaluation of new business models discussed. It has been stated that start-up methodology is an optimal way to approach market, based on specific requirements. 3 main success factors for it were prescribed in research as follows:

1. to do things differently from the status quo,

2. to bolster the competencies required for the new business model, and

3. to continuously and endlessly strive for the change to happen [6].

The authors also inputted that the results of research on value drivers, which comprise the successful model. They are classified as Innovations, lock-in, protection from competition, and efficiency $[19,6]$. The emphasis is on the key activities and key resources that outline a business area, estimating the output in market attractiveness as well as competitiveness. This evaluation gives the obligatory path to rearrange assets and gives ability to provide a unique product or service.

Another interesting approach, which is tested by Kim and Mauborgne [6] on how to innovate a business model called Creating Blue Oceans. The basis of the model is to take the industry standard and use it as a reference point when creating a customer-centric business model. The focus is to create an advantage against the market's standard value proposition. The Blue Oceans model is suitable and works well with the business model canvas as concept, which is applicable to the whole canvas model.

In order to be a successful business, organizations should be able to challenge themselves on a number of issues and also review the dynamics of the respective mechanisms which are:

- offered value to customers [strategic goals and value proposition];

-scope of offerings;

-pricing strategy;

-appropriate revenue model;

- calculated and estimated list of required resources and all expected costs to provide the value to final customer [6]. In case of Business Model Innovations, Organizations should be able to understand and capitalize on the distressing issues of the electronic world and e-commerce to renovate their business models for future success. Actually, the major researchers agreed on the statement, that Business model innovation nowadays is mainly based on proper use of new knowledge [technological and market based] that to design and implement an innovative way of product offerings and services for segmented customers [6]. One of the well-know cases of successful business model innovations that were able to capitalize on some of the troublemaking features of the Internet include channel innovation [e.g., Dell's build-to-order virtual integration model], process innovation such as Boeing virtual design and eprocurement, customer-relationship (e.g., Yahoo!), and affiliate network (e.g., Amazon) [6].

Rachinger and other authors in their study emphasised that, one of the methods and tools to renovate business model and make it more related to the digital world is implementation of E-commerce tool. It is useful to implement as a supporting innovation to boost existing business of the company. In that case, companies might be unsuccessful to recognize and profit from on many of the Internet's opportunities. Thus, in order to benefit from all advantages, the "disruptive attributes" or types of ecommerce innovation must be recognized and applied in a practical business model [6].

Furthermore, in theories, one of the successful and useful tools for development of business model and proper identification of key activities is known as the business model canvas structure [6]. The model can separate processes and key activities from total value proposition and representation of reasons for considering as key and non-key activities.

One of the main advantages of the business model canvas is the fact that it represents business plan in one page [14].

During the process of development of the business model, several ideas have be taken into consideration and one thing emphasized by Osterwalder and Pigneur [2] is the concept should be consumer oriented or as known customer centric. It means that all choices made regarding the value proposition, distribution channel, customer relationship and revenue stream all should tie back to your intended customers. These segments are directly linked to the customer segment and together they form the core of the business itself, remaining 
segments form a foundation for them to work but without a solid core structure, the model will not work [4].

Osterwalder's business model framework

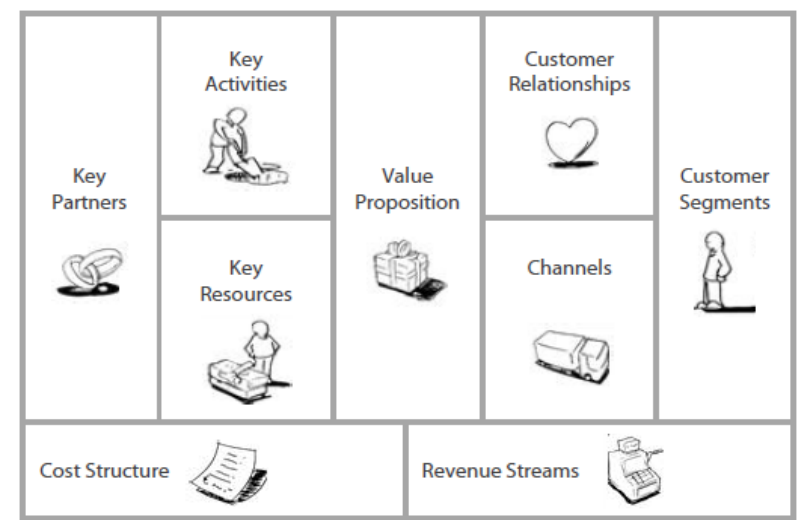

Fig 3. Osterwalder and Pigneur Business model innovations

However, in the studies of Osterwalder and Pigneur [19], it was also argued that Business model should be viewed as a holistic concept that embraces all organisations part:

1. Complex system

2. Holistic concept with many organisational parts

3. Functioning in dynamic business environment

The business model approach presented by Osterwalder and Pigneur is widely used by organisations and it also gives opportunity to be successful [23].

One of the famous and well used models is proposed by Boston Consulting group which consist of 2 elements value proposition and operating model [23]. In general 6 sub elements which are illustrated below in figure 4 helps companies to identify structural way to identify key areas to change and practical to develop relevant model.

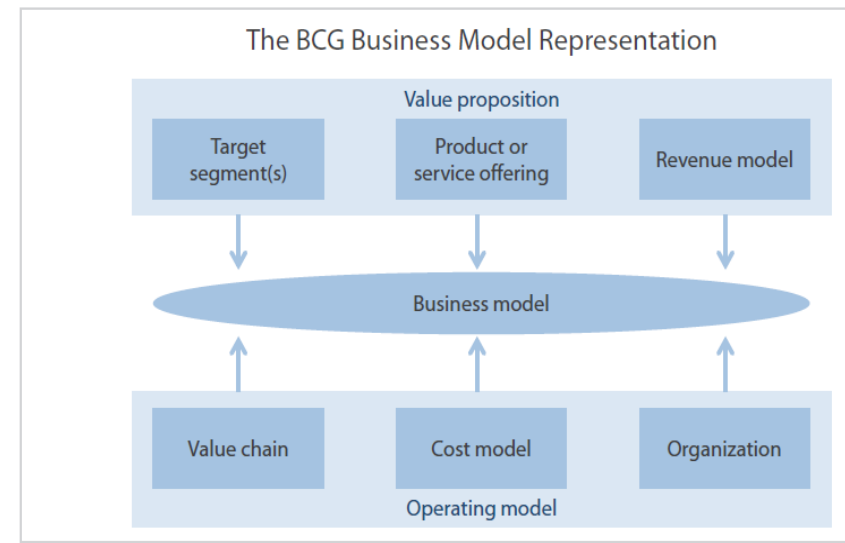

Fig 4 Boston Consulting group Business model representation

According to the research on digital transformation and its success factors [8], company should have a valuable and effective business model, with strong digital capabilities, and it is achieved by the implementation of these digital tools. However, they have respectively, severe impact on the operation processes, resources management, internal and external consumers of the organization [8].
Proper business model with consideration of innovative tools and digitalization will improve business processes of the organization, improve efficiency, quality and consistency, also it helps to reduce manual processes [7]. Digitalization helps in improving the business process efficiency, quality and consistency, which results in effective internal efficiency of organization; this can be achieve by eliminating the existing manual process and maintain better accuracy [8]. Taking into consideration the increasing importance of digital business models for modern enterprises and the fundamental changes they cause, the proposed theories will also affect future corporate management tools. In general, based on the pace of changes and innovations appearing in the market, total business management concepts, the requirement for in depth analysis for business model development and its implications should be reconsidered and updated.

The speed of these technological changes and use of these great challenges as an opportunity, made variety of business stronger and successful [9]. As it was stated in the article, the era of digitalization and being able to react on these changes, made start-up companies like Airbnb and Uber to multi-billion dollar companies, within a short period of time [6]. As it was mentioned above in Introduction section, the leading companies (Google, Uber, Amazon) have totally broke stereotypes and business rules in their respective industries by changing the basic building blocks of their business models [1]. After researching more closely on these cases, authors identified that the source of competitive advantage has change. Now, unique model is more applicable and valuable, rather that innovative products and services. Innovations on Business model facilitated these companies to gain higher sales, better profit margins and more cash flows than other players in the market. Actually, these companies are lack of clear value chain and without any fixed charges (in machinery, equipment's) [1].

As per findings of Economist Intelligence Unit (2012) which had survey with more than 4,000 executive managers around the world on the topic innovativeness in business [1]. According to findings, these senior managers highlighted that, they gave preferences to business models as a competitive advantage rather than developing new products and services. Additionally, one of the previous and first studies by IBM (2006) emphasized that due to rigorous global pressures, high level management shift the focus and interest towards to business model innovations. It was also mentioned there, that companies with best results in the market and who beaten the competitors and who grew on rapid speed, were mainly focused on successful business model creation.

In the same research done by IBM (2006), which is discussed in the paper of Bashir and Verma [1], it was stated that in 2006 major CEOs spent about 30\% of their time in the endeavor to find best solution for business by innovating their business models.

The study also underlined that companies gained higher profits with the use of new innovative business. $40 \%$ of senior managers surveyed stated firms put 
efforts, energy and resources to be the first to drive the change and be a leading competitor in the market, rather than being the one who will follow others. Furthermore, list of benefits from integration of innovations in business model were also presented in this report, where more than $50 \%$ (surveyed) of the directors mentioned that it may reduce costs and allow a strategic flexibility. Also, more than $40 \%$ of executive respondents encouraged that innovative business model gives new market opportunities, helps to renew focus [1].

Another Researcher Eksell and Harenstam [6], in their report illustrated that in general, innovations in the business model leads to number of positive changes in the company. In their case study analysis, they identified that companies who innovated business model successfully, reduced costs, boost better performance. However, they also faced to major limitations and obstacles [6]. The Researcher mentioned that this process takes strong team and takes time. It is improper to follow market trends and try to quickly and temporary fix existing business model to be competitive in the market [6].

Furthermore, different academic researchers identifies the variety level of innovations in the business model [19]. While one definitions stating that its moving from old business model to new one, other scholars debating that it's the process of adding innovations into existing model. There is no right answer as the methods and approaches for each business model will vary during implementation [23]. Breiby and Wanberg, in their report on successfulness of the innovation of business models illustrated the challenges in the implementation of both methods. In order to make successful the process of innovation of business model, all proper stages (which is presented in their paper [23]) should be managed. Also, the importance of analysis of existing (current\} model helps more to identify week point as it is challenging to forecast how far business model should be innovated and how will work [23].

The researchers in their scholarly written reports conclude that in current aggressive competitive world, business model innovation are more applicable and relevant to implement, as new products and others can easily copy products or services. Innovative Business model is an alternative solution for future growth, allows gaining sustainable revenues and helping to earn four times more returns than product innovators [1].

\subsection{Results identified based on literature review}

The scholars, which were stated on these papers, did a significant research on the issues related to innovations of business model and its influence to the core business. In the findings of the research conducted by Tesarova, the b2b large market companies benefited significantly by applying the innovations through digitalization to the core business model, they gained higher customer value and in major cases, the companies adapt incrementally changes by that got higher opportunities to grow [16].

The table below summarizes key points identified from the literature review. It illustrates the theoretical framework for the innovations on business model and its success factors.

Table 1. Summary of key points from Literature Review

\begin{tabular}{|c|c|}
\hline Element & Key points \\
\hline $\begin{array}{l}\text { Business } \\
\text { model }\end{array}$ & $\begin{array}{l}\text { Business model is considered as a logical key } \\
\text { to perform, a system approach to create a value } \\
\text { for its stakeholders. } \\
\text { Business models for a company also known as } \\
\text { a plan or a strategy that describes value chain } \\
\text { delivery to final customers } \\
\text { A business model innovation is a new approach } \\
\text { to create value for customers taking into } \\
\text { consideration digital changes, and how this } \\
\text { value is carried or how the business gains } \\
\text { profits from the service/product offered to the } \\
\text { customer }\end{array}$ \\
\hline $\begin{array}{l}\text { Classicific } \\
\text { ation of } \\
\text { business } \\
\text { models } \\
\text { according } \\
\text { to } \\
\text { researche } \\
\text { rs }\end{array}$ & $\begin{array}{l}\text { 1.Zott and Amit analyzed and presented that in } \\
\text { a effective and successful business model is } \\
\text { general system of activities correlated with each } \\
\text { other and consequently, during the process of } \\
\text { innovating business process } 2 \text { parameters: } \\
\text { design elements and design themes for activity } \\
\text { system should be done } \\
\text { 2. Lee and Vonortas in their research, } \\
\text { mentioned that a business model comprises of } \\
\text { multiple components or elements which is } \\
\text { about behavioural and structural correlation } \\
\text { between them } \\
\text { 3. Rayport and Jaworski researchers illustrated } \\
\text { that business model is based on } 4 \text { choices, such } \\
\text { as a "value proposition, coverage of different } \\
\text { type of products services or information (or } \\
\text { combination of all of them) for covering market } \\
\text { needs; secure resource system and model for } \\
\text { financial system } \\
4 . \text { Johnson, Christensen and Kagermann } \\
\text { illustrated the four elements for innovating } \\
\text { business model that in total create, deliver and } \\
\text { capture value. } \\
5 \text {. Osterwalder and Pigneur, - argued that } \\
\text { Business model should be viewed as a holistic } \\
\text { concept that embraces all organisations part: } \\
\text { 1. Complex system } \\
2 \text {. Holistic concept with many organisational } \\
\text { parts } \\
3 \text {. Functioning in dynamic business } \\
\text { environment } \\
\text { The business model approach presented by } \\
\text { Osterwalder and Pigneur is widely used by } \\
\text { organisations and it also gives opportunity to be } \\
\text { successful } \\
6 \text {. One of the famous and well used models is } \\
\text { proposed by Boston Consulting group which } \\
\text { consist of } 2 \text { elements value proposition and } \\
\text { operating model [23]. In general } 6 \text { sub elements } \\
\text { which are illustrated below in figure } 4 \text { helps } \\
\text { companies to identify structural way to identify } \\
\text { key areas to change and practical to develop } \\
\text { relevant model. }\end{array}$ \\
\hline Features & $\begin{array}{l}\text { Business model innovation consist of different } \\
\text { types of innovation, based on it the scope in the } \\
\text { model are changed } \\
\text { New business models can fully integrate with }\end{array}$ \\
\hline
\end{tabular}




\begin{tabular}{|l|l|}
\hline & $\begin{array}{l}\text { the old business model or may partially replace } \\
\text { it } \\
\text { Researchers explain business model innovation } \\
\text { as an cyclical process going over different } \\
\text { stages of designing and implementing business } \\
\text { models. } \\
\text { For successful integration of innovations in } \\
\text { business models, they should be competitive } \\
\text { and hard to understand and copy for other } \\
\text { market players. }\end{array}$ \\
\hline $\begin{array}{l}\text { Result } \\
\text { from } \\
\text { implemen } \\
\text { tation of } \\
\text { innovatio } \\
\text { ns in } \\
\text { Business } \\
\text { model }\end{array}$ & $\begin{array}{l}\text { In case of successful implementation of } \\
\text { innovation in the business model, the success of } \\
\text { the company is its competitive advantage over } \\
\text { market which help to gain higher customer } \\
\text { satisfaction and respectively profit for the } \\
\text { company }\end{array}$ \\
\hline
\end{tabular}

One of the newly published studies presented by famous consulting agency McKinsey, illustrates that major innovation in business comes after getting over the crisis [22]. In 2020, one of the largest crisis for the world is the COVID-19 pandemic, which affected almost everyone from all businesses to each person. Their current survey consisted of more than 200 organizations across industries, where more than 90 percent of managers said they expect the significant consequence from COVID-19, which will change business processes and the way the business is done. Furthermore, it will definitely influence the customer needs and preferences. The survey also identified that the key focus of the executives now is to sustain business continuity; they have to evaluate cutting costs, motivating productivity, and holding employees beside innovation to business growth As a result, innovations in business are least priority investment. However, the managers from conducted survey strongly believe that innovations in business are very important and as soon as the world is stabilized, companies will return to these investments. Moreover, McKinsey's survey and interviews conducted with business heads indicates that, innovations were not prioritized into their business as they plan to concentrate on following activities:

- Reinforce the core business of the company by following recognized opportunity spaces, maintaining cash and minimizing risk, until clarity of the future actions will be identified

- Adaptation of the core of the business to meet changed customer needs

- Clarify and rapidly address new opportunity zones

- Reevaluate portfolio of the innovation initiatives and allocate resources properly

- Build the basis for post crisis development in order to persist competitive in the recovery period

The businesses should take into consideration, that it will never operate as they used to do it in the past.

As the business model starts adapting to new market changes, the Competitive advantages changes dynamically, because the core competences that distinguish the business from others might become suddenly less attractive. While the rise of digital has been mounting similar pressures for more than a decade, the current crisis has significantly exacerbated and accelerated its disruptive force.

To summarize, the outcomes indicates that one of the reasons why business models are innovated is due to a fear of being replaced by a competitor. The change is happening on a daily basis. Consequently, companies who wisely created and developed their existing strategies and innovated existing business models with proper methods, are becoming successful. The advantage of innovative business model in the current work is very high for the successful companies.

\subsection{Results identified from Interviews}

The data collection based on the interview is mainly depend on the participants level of strategic insight about the company, his openness and knowledge. Researcher was able to conduct interview with deputy directors of the banks, as they are one of the representatives and knowledgeable person. Several management level respondents declined the request for the interview, thus only few was identified.

One of the Banks (Bank A) in Uzbekistan which is known in the market as a Mortgage Bank is opersting in the market for several decades. Currently. it is in the process of innovating its business model. As per discussion with the management, the reason for this decision was based on the governement level. The central Bank of Uzbekistan, requested the bank to be more technologically efficient and digitalize. The main problem of the Bank was, it was not customer oriented, the services were time consuming and in general the existing system was outdated. It tried to be competitive by inventing new products, new design of services, by hiring high skilled personnel. However, without updating and innovating the model itself, the results were not achieved. As a result, in 2017 the bank started working on changing the structure, innovating its business model.

The Deputy Director of the Bank stated that it is already 4 years and results are not achieved yet.

The obstacles they faced :

- Expensiveness of innovations on existing model

- Time consuming

- Due to digitalization and It excellence of new model, major other areas should be changed

On the Other hand, partial implementation of new innovative business model, already help bank to reduce costs and create better reputation in the market. According to the Banks predictions, by 2023 the bank will become in top 3 banks in the market as a technogically shift and highly profitable.

The second Bank (Bank B) is the largest government bank and is also in process of implementing innovations in Existing business model. The researcher had chance to have a interview with the head of Strategy department, which is in charge of this change project. The Bank is planning to innovate whole business model within 3 years.

The reason for implementing Innovative business model is to become highly competitive and gain higher 
profits. As per analysis of Business Intelligence Team of the Bank B, the forecasts done on the results of innovations in Business model shows very good results. The Bank B will become number one bank in the market for its stakeholders.

As per interview results, The Bank B decided to innovate its business model by creating customer centric. Currently, due to very high risks and difficulty level on innovations, bank decided to implement them in step-by-step mode.

\section{Conclusion}

The findings on the theoretical research by analysing the literature review is presented in this paragraph. After the review of all research and findings of studies and investigations, it was identified that in this changing market, the organizations have to be able to make a proper examination of the existing model and based on industry requirements, competition in the market. In general, Innovative Business model is a powerful tool for succeeding in business, for being updated in the market and to gain competitive advantage. It was also analysed that, old market strategies like Porters on new product development and optimization of value chain as an competitive has been effective advantage. In current social and digitalized era, the modern companies try to distinguish themselves in order to be profit oriented. Moreover, the startups, and companies which are influenced by technologies and who were able to implement digital mechanism into the business becoming more popular and showing to the market the win strategy [1]. As it was mentioned above, some of the big entities such as Google, Amazon and newly emerged in the last half decade Airbnb, Uber are changing the ground rules in the market by their innovative style of business. These technologically developed companies stress on mainly on the idea of innovating their business model, rather than concentrating on fixed value chains. They are result of successfully planned business with high margins and turnover. Accordingly, the studies show that in the era of technology and digital revolution, companies are more concentrated on the competent development of Innovative business model. The companies should not spent time and resources, and put high emphasis on the development of new products and services with an existing business model. Different studies are showing that it will not gain competitive advantage in the market. The study held by different researchers has reasoned that business model innovation can be functioned as a viable competitive advantage as imitation of entire the business model is not easy and affordable as imitation of new product in the competition [13].

Nevertheless, Innovative Business model tool is still not highly popular among companies. It is still under the process of full implementation and has to be vital for existing and new businesses to use for success and digitalize in the new economic era. All the opportunities and challenges organizations may face during the process of business model changes, for example, by using digital technologies was discussed. This summarized information signifies a valued, significantly relevant contribution to the sectors that absences on an empirical foundation. According to Amit et al. [19] strategies in the management level strategy has to be used business model frameworks in order to identify the correct business model innovation for the specific situation, and how to apply it, before proceeding with the implementation. The Success of implementation and success of the business in current digitalized economic conditions relies on both, getting the model right and making sure that the compulsory business does not offset the new model [6]. Furthermore, according to the results of the interviews conducted with the largest banks in the Uzbekistan, clarifies that Innovations in business models is very expensive and strategic tool and it should not be used only for competition, but for strategic growth of the company. In case of using wisely this method, the companies will benefit and succeed in the future, To finalize, a practical innovative business model will be able to cover the essential economic principles of the market (various costs and revenue/pricing models) and give company opportunity to minimize extra costs [13]. Also, they have to be able to detect and get the most out of on the disruptive attributes of Internet commerce. Moreover, it should be developed based on the general picture, vision and strategy of the company. Additionally, the inability to implement the innovative business models and not being able to catch the pace of new digitalized economic factors may lead to the failure of existing large businesses and organizations. Thus, nowadays, the digital world dictates the rules and creates great opportunities for the market, only if they are used properly. Therefore, the only mechanism that will have substantial value and effect in the near future is managing the technological shifts in the company's business, by innovating the business model upon the rivalry. Innovating the Business model is not easy process, it is more challenging, expensive and time consuming than the product and process innovation, but the paybacks derived out of it are also superior. It will not only sharply increase the profit of the company, but also will help to reduce costs and optimize the business itself [1] Moreover, it is very vital for CEOs to deeply analyse the existing model and identify the limitations, before taking opportunities and innovate the business model. Finally, the research on implications of business model innovation and its importance is still at a potential stage. There is a huge research gap in this area. Besides, there is a deficiency of a practical method for how companies should follow business model innovation in the digitalization framework. There is still lack of literature and researches, same as businesses, which are lack of the knowledge of how to perform business model innovation, which method to use and the prediction of results from these changes. Nevertheless, the existing studies are proving the innovations in business model will help to improve the future progress and sustainability of the business in this digitally changing world. 


\section{References}

1. Bashir M., Verma R, Why Business Model Innovation Is the New Competitive Advantage. IUP Journal of Business Strategy. Mar2017, Vol. 14 Issue 1, p7-17. 11. (2017) Available at SSRN: https://ssrn.com/abstract $=3175788$

2. Ricart, J. E. "Business Models for the Companies of the Future." In Reinventing the Company in the Digital Age. BBVA (2014) https://www.bbvaopenmind.com/en/articles/busine ss-models-for-the-companies-of-the-future/

3. Mendelson, H. "Business Models, Information Technology, and the Company of the Future." In Reinventing the Company in the Digital Age. Madrid: BBVA, (2014)

https://www.bbvaopenmind.com/en/articles/busine ss-models-information-technology-and-thecompany-of-the-future/

4. C Zott, R. Amit, \& L. Massa, The business model: Theoretical roots, recent developments, and future research (2010) DOI:

,http://doi.org/10.1177/0149206311406265111.62 85

5. D.J. Teece, Business Models, Business Strategy and Innovation. Long Range Planning (2010) DOI: https://doi.org/10.1016/j.lrp.2009.07.003

6. A. Eksell and A. Harenstam, Business Model Innovation for a digital future (2017) Available at: https://pdfs.semanticscholar.org/05eb/dc8412edd5f 425cb27f84eace1 baff5ec100.pdf

7. C. S. Lee, \& N.S. Vonortas, Business Model Innovation in the Digital Economy. 1[3], 292-312. (2014) DOI: http://doi.org/10.4018/9781599049472.ch260

8. M. Rachinger, R. Rauter, CH. Muller, W. Vorrabor, E. Schirgi. Digitalization and its influence on business model innovation. EmeraldInsight Vol. 30 No. 8, pp. 1143-1160 (2018) DOI http://doi.org/10.1108/JMTM-012018-0020

9. C. S. Lee, \& N.S. Vonortas. Toward an integrated model of strategy formulation for strategic technical alliances. (2004) DOI: https://doi.org 10.1504/IJTTC.2002.001790

10. OECD, "Exploring Data-Driven Innovation as a New Source of Growth: Mapping the Policy Issues Raised by "Big Data", OECD Digital Economy Papers, No. 222, OECD Publishing, Paris. (2013) DOI: http://doi.org/10.1787/5k47zw3fcp43-en.

11. OECD. "The digital economy, new business models and key features", in Addressing the Tax Challenges of the Digital Economy, OECD Publishing, Paris. \{2014) DOI: https://doi.org/10.1787/9789264218789-7-en

12. C. S. Lee, Y.G. Chen and Y.H. Fan, Structure and Components of E-Commerce Business Model (2006) DOI : https://doi.org/10.4018/9781591407997.ch170
13. Tesarova M., Krmela A., Simberova I., Digitalization as an enabler of business model dynamics. (2020) DOI: https://doi.org/10.3846/bm.2020.562

14. U. Umihana, Business Model Innovation as a New Source of Competitive Advantage - A Case Study based on the Energy Sector., Research Gate (2014) DOI: http://doi.org/10.13140/RG.2.2.16812.26244

15. S.J. Berman, Digital transformation: opportunities to create new business models. Strategy Leadership. (2014) DOI: http://doi.org/10.1108/10878571211209314

16. R. Mustafa, Business model innovation. Journal of Strategy and Management, 8 (4), 342-367 (2015) DOI: http://doi.org/10.1108/JSMA-062014-0054

17. What-When-How, Business Model Innovation in the Digital Economy, https://what-whenhow.com/information-science-andtechnology/business-model-innovation-in-thedigital-economy/

18. R. Alt, \& H. Zimmermann. Preface: Introduction to special section - business models. (2001) DOI: http://doi.org/10.1080/713765630

19. A. Osterwalder, Y. Pigneur. Business Model Generation: A Handbook for Visionaries, Game Changers, and Challengers. (2010) DOI: https://doi.org/10.1080/14719037.2020.1718187.

20. M. Dubosson-Torbay, A. Osterwalder, \& Y. Pigneur, E-business model design, classification, and measurements. (2002) DOI: https://doi.org/10.1016/j.lrp.2009.07.003

21. C Zott, R. Amit, \& L. Massa, The business model: Theoretical roots, recent developments, and future research (2010)

DOI:http://doi.org/10.1177/014920631140626511 1.6285

22. BarAm J., Furstenthal L., Jorge F., and Roth E., Innovation in a crisis: Why it is more critical than ever (2020) Available at: https://www.mckinsey.com/businessfunctions/strategy-and-corporate-finance/ourinsights/innovation-in-a-crisis-why-it-is-morecritical-than-ever

23. Breiby E. and Wanberg M., Successful business model innovation (2011) Available at: https://core.ac.uk/download/pdf/52108745.pdf 